\title{
COMMUTATORS OF MARCINKIEWICZ INTEGRALS WITH ROUGH KERNELS ON HERZ-TYPE HARDY SPACES WITH VARIABLE EXPONENT
}

\author{
HONGBIN WANG AND DUNYAN YAN
}

Abstract. Let $\Omega \in L^{s}\left(\mathrm{~S}^{n-1}\right)$ for $s \geqslant 1$ be homogeneous functions of degree zero and $b$ be BMO functions. In this paper, we obtain some boundedness of the Marcinkiewicz integral operator $\mu_{\Omega}$ and its commutator $\left[b, \mu_{\Omega}\right]$ on Herz-type Hardy spaces with variable exponent.

Mathematics subject classification (2010): 42B20, 42B35.

Keywords and phrases: Herz-type Hardy space, variable exponent, commutator, Marcinkiewicz integral.

\section{REFERENCES}

[1] C. Capone, D. Cruz-URibe, SFO And A. Fiorenza, The fractional maximal operators and fractional integrals on variable $L^{p}$ spaces, Rev. Mat. Iberoamericana, 2007, 23: 743-770.

[2] D. Cruz-URibe And A. FiorenzA, Variable Lebesgue Spaces: Foundations and Harmonic Analysis (Applied and Numerical Harmonic Analysis), Springer, Heidelberg, 2013.

[3] D. Cruz-Uribe, A. Fiorenza, J. M. Martell and C. PÉrez, The boundedness of classical operators on variable $L^{p}$ spaces, Ann. Acad. Sci. Fen. Math. 31 (2006) 239-264.

[4] L. Diening, P. Harjulehto, P. HÄstö And M. RŮŽIČKA, Lebesgue and Sobolev spaces with variable exponents, Lecture Notes in Math., vol. 2017, Springer, Heidelberg, 2011.

[5] Y. Ding, D. FAN AND Y. PAN, Weighted boundedness for a class of rough Marcinkiewicz integral, Indiana Univ. Math. J. 48 (1999) 1037-1055.

[6] Y. Ding, S. Lu And K. YABUTA, On commutators of Marcinkiewicz integrals with rough kernel, J. Math. Anal. Appl. 275 (2002) 60-68.

[7] M. IZUKI, Boundedness of sublinear operators on Herz spaces with variable exponent and application to wavelet characterization, Anal. Math. 36 (2010) 33-50.

[8] M. IZUKI, Boundedness of commutators on Herz spaces with variable exponent, Rend. del Circolo Mate. di Palermo 59 (2010) 199-213.

[9] O. KovÁčiK AND J. RÁKosník, On spaces $L^{p(x)}$ and $W^{k, p(x)}$, Czechoslovak Math. J. 41 (1991) 592-618.

[10] Z. LIU AND H. WANG, Boundedness of Marcinkiewicz integrals on Herz spaces with variable exponent, Jordan J. Math. Stat. 4 (2012) 223-239.

[11] S. LU, Y. Ding AND D. YAN, Singular Integrals and Related Topics, World Scientific Press, Beijing, 2011.

[12] S. Lu And D. YAng, The continuity of commutators on Herz-type spaces, Michigan Math. J. 44 (1997) 255-281.

[13] E. NAKAI AND Y. SAWANO, Hardy spaces with variable exponents and generalized Campanato spaces, J. Funct. Anal. 262 (2012) 3665-3748.

[14] E. M. Stein, On the function of Littlewood-Paley, Lusin and Marcinkiewicz, Trans. Amer. Math. Soc. 88 (1958), 430-466.

[15] J. TAN AND Z. LiU, Some boundedness of homogeneous fractional integrals on variable exponent function spaces, Acta Math. Sinica (Chin. Ser.), 58 (2015) 309-320. 
[16] H. WANG, Z. FU AND Z. LIU, Higher-order commutators of Marcinkiewicz integrals and fractional integrals on variable Lebesgue spaces, Acta Math. Sci. Ser. A Chin. Ed. 32 (2012) 1092-1101.

[17] H. WANG AND Z. LiU, The Herz-type Hardy spaces with variable exponent and their applications, Taiwanese J. Math. 16 (2012) 1363-1389.

[18] H. WANG AND Z. LiU, Some characterizations of Herz-type Hardy spaces with variable exponent, Ann. Funct. Anal. 6 (2015) 224-243. 